\title{
Social Policy Heritage of the UN and European Countries Related to Elderly Persons
}

\section{Introduction}

The rule of law is a set of ideas and practical procedures aimed at promoting the understanding that the law should prevail and that all legal proceedings should be subject to due process of law rather than the arbitrary will or decisions of participants involved in these processes. Besides the need of having ideas that inspire political societies to accept the rule of law, it is also necessary to provide a well-established practice of incorporating the rule of law principles into social reality and to apply them in practice. ${ }^{2}$

The notions of aging and living at old age do not remain solely in the domain of sociological, criminological, victimological or medical studies, debates and research. They are, first and foremost, part of the core of basic human rights, regulated by explicit international and domestic legal norms. In Serbia, the national legal standards have been harmonised with all ratified international legal documents guaranteeing the fundamental rights of man, such as: the prohibition of discrimination, the right to life and health care, the right to social support and maintenance, and, in particular, the protection in the field of social needs of elderly persons. In order to raise general public awareness about these issues, it is necessary to examine basic UN documents as well as those adopted by the European Union and the Council of Europe, which constitute a lexicon for incorporating good social policy practice towards the elderly into national legislation.

1 Darko Dimovski, LL.D., Associate Professor, Faculty of Law, University of Niš; Miomira Kostić, LL.D., Full Professor, Faculty of Law, University of Niš.

2 See: Konstantinović-Vilić, S., Kostić, M., Miladinović, D., The right to legal aid and the quality of legal assistance rendered to citizens in criminal proceedings and the procedure of serving sentences, Faculty of Law, University of Niš, Publications Centre, Niš, 2007, p. 15. 


\section{United Nations}

The initial interest of the UN member states in the overall status and social position of elderly people may be traced back to 1969 . On 16 December 1969, the UN General Assembly adopted the Resolution 2599 (in its XXIV session), where the General Assembly regrets being unable to examine the question of elderly people at its 24th session, owing to the comprehensive agenda, and "decides to give priority and adequate consideration to this issue at its twenty-fifth session." ${ }^{3}$

However, the issue of aging and the position of elderly people was first discussed at the 26th session of the General Assembly of the United Nations, on 18 December 1971, when the UN General Assembly adopted Resolution 2842 (XXVI). This Resolution raised specific requests before the Secretary-General and the UN Member States, including inter alia a request to "continue to study the changing socio-economic and cultural role and status of elderly people in countries of different levels of development and to prepare, within existing sources and in cooperation with the International Labour Organisation, the World Health Organisation and others interested specialised agencies, a report suggesting guidelines for national policies and international action related to the needs and the role of the elderly and the aged persons in society, in the context of overall development, particularly in countries where the socio-economic difficulties of the elderly are observed." ${ }^{4}$

At the XXVIII session of the UN General Assembly, on 14 December 1973, the General Assembly adopted Resolution 3137, which sets out in greater detail the tasks to be addressed by the Governments of the UN Member States regarding the short-term and long-term policies for the elderly. The specific recommendations for appropriate action include as follows: a) to develop, in accordance with national priorities, social welfare programmes, health care and protection programmes for elderly persons; b) to progressively develop social security measures to ensure that elderly people receive adequate income and support, irrespective of gender; c) to increase the participation of the elderly in social and economic development; d) to discourage, whenever possible, discriminatory attitudes, policies and measures in employment practices, which are exclusively based on age; e) to encourage the creation of employment opportunities for the elderly in accordance with their needs; f) promote, by all possible means, the strengthening of the family unit/community; g) to stimulate bilateral and

3 See: 2599 (XXIV) Question of the elderly and the aged, 16 December 1969, https:// documents-dds-ny.un.org/doc/RESOLUTION/GEN/NR0/257/33/IMG/NR025733. pdf?OpenElement (accessed 11.11.2018).

4 See: 2842 (XXVI) Question of the elderly and the aged, 18 December 1971, https:// documents-dds-ny.un.org/doc/RESOLUTION/GEN/NR0/328/58/IMG/NR032858. pdf?OpenElement (accessed 14.11.2018). 
multilateral agreements on cooperation in the field of social security for the benefit and well-being of the elderly. ${ }^{5}$

At the 105th plenary session, held on 16 December 1977, the UN General Assembly adopted Resolution 32/131, which invokes all previous recommendations and outcomes addressed by the Member States and, for the first time, emphasises the importance of implementing the Declaration on Social Progress and Development, adopted on 11 December $1969,{ }^{6}$ by which the General Assembly proclaimed the necessity of protecting the rights and ensuring the necessity of the social welfare of the elderly. With reference to the recommendations to the Governments of the Member States introduced by Resolution 3137 (XXVIII) of 1973, Resolution 32/131 elaborated on the request to the UN Secretary-General to continue and expand activities in this area, as follows: a) to consider measures for strengthening the activities of regional commissions established to assist in the planning, establishment and improvement of social and health services for the elderly; b) to assist Governments, at their request and in accordance with national priorities, in planning, establishing and expanding programs for the elderly population in the context of their overall development programs; c) to organise seminars and workshops, and to conduct research in this area, especially on the problems encountered by the elderly in the developing countries; d) to conduct research on the possibility of preserving and promoting the empowerment of the family unit/community in a way that facilitates, where possible, the care of the elderly and the aged by their own family; e) to collect, compare and disseminate information through the Information Exchange System. ${ }^{7}$ At that same session of the General Assembly, Resolution 32/132 established the International Year and the World Assembly on Aging. Referring to the Declaration on Social Progress and Development of 11 December 1969 as well as its emphasis on the dignity and worth of the human being and the rights of the elderly, Resolution $32 / 132$ invited the states to exchange experiences and opinions, to promote mutual cooperation in raising worldwide attention to the serious problems encountered by the aging and elderly population worldwide, and to devise programmes to tackle these problems. ${ }^{8}$

5 See: 3137 (XXVIII) Question of the elderly and the aged, 14 December 1973, https://documents-dds-ny.un.org/doc/RESOLUTION/GEN/NR0/282/09/IMG/ NR028209.pdf?OpenElement (accessed 15.11.2018).

6 Declaration on Social Progress and Development 2542 (XXIV), 11 December 1969, https://www.ohchr.org/Documents/ProfessionalInterest/progress.pdf (accessed on 16.11.2018).

7 Resolution 32/131 Question of the elderly and the aged, 16 December 1977, http:// www.un.org/documents/ga/res/32/ares32r131.pdf (accessed 3.12.2007).

8 Resolution 32/132 International year and world assembly on aging, 16 December 1977, http://www.un.org/documents/ga/res/32/ares32r132.pdf (accessed 3.12.2007). 
The UN took another step in regulating issues pertaining to the protection of elderly people. On 14 December 1978, the General Assembly adopted Resolution 33/52 where the General Assembly decided to establish specialised agencies and relevant organisations and, in consultation with the Member States, reached an agreement that the World Assembly on the Elderly be held in 1982 as a forum to launch an international action programme aimed at guaranteeing economic and social security to the elderly, as well as to provide opportunities for them to contribute to the national development. ${ }^{9}$

The first World Assembly on Aging was held in Vienna in 1982. This forum adopted the Vienna International Plan of Action on Aging as the first international instrument specifically dedicated to aging. This document sets out the basis for the formulation of policies and programmes on aging. The plan adopted at the First World Assembly on Aging in Vienna contained recommendations on different activities related to research, data collection and analysis, training in the field of aging as well as certain activities related to nutrition and health, protection of elderly users, housing and environment, family, education, social security, material security and employment. ${ }^{10}$ The plan was endorsed by the UN General Assembly (at the 90th plenary meeting of 3 December 1982), by Resolution 37/51 which encourages different activities in the field of research, data collection and analysis, training centres in the field of aging, ensuring resources for effective implementation of the plan, assistance to developing countries, involvement of intergovernmental and non-governmental organisations, networking and international cooperation, etc. ${ }^{11}$

On 16 December 1991, the UN General Assembly adopted Resolution 46/91, which introduced the United Nations Principles for Older Persons. ${ }^{12}$ The Governments of the UN Member States were encouraged to incorporate into their national programmes the following principles: independence; participation; care; self-fulfilment; and dignity. ${ }^{13}$

In October 1992, the UN General Assembly adopted Resolution 47/5, the Proclamation on Aging, which promoted international and interregional cooperation in support of national initiatives and raising general public awareness on aging. The Resolution proclaimed 1 October to be the International Day of Elderly and 1999 was declared the International Year

9 Resolution 33/52 World Assembly on the Elderly, 14 December 1978, http://www. un.org/documents/ga/res/33/ares33r52.pdf (accessed 3.12.2007).

10 UN - Key conference outcomes on ageing, http://www.un.org/esa/devagenda/ aging.html (accessed 30.11.2007).

11 Resolution 37/51 Question of Ageing, 3 December 1982, http://www.un.org/ documents/ga/res/37/a37r051.htm (accessed 10.9.2018).

12 United Nations Principles for Older Persons, https://www.ohchr.org/en/professionalinterest/pages/olderpersons.aspx (accessed 11.11.2018).

13 For more, see: United Nations Principles for Older Persons. 
of Elderly Persons. ${ }^{14}$ It was also agreed that the Second World Assembly on Ageing was to be held in Madrid (Spain) in 2002, whereas Germany offered to host the Ministerial Conference on Aging in Berlin. ${ }^{15}$

During 2000, the UN General Assembly adopted Resolution 55/2 of 8 September 2000, the UN Millennium Declaration. ${ }^{16}$ The significance of the provisions of the Millennium Declaration in terms of the status and quality of life of elderly persons all over the world is that the document determines the fundamental values that should be essentially represented in international relations in the 21 st century. They include:

- freedom (men and women have the right to live their own lives and raise their children in dignity, free from fear of hunger, violence, oppression or injustice);

- equality (no individual or nation should be denied the opportunity to enjoy the benefits of development);

- solidarity (global challenges must be managed in a way that distributes costs and burdens fairly in accordance with the basic principles of equality and social justice; those who suffer or benefit least deserve help from those who benefit most);

- tolerance (human beings must respect each other, in all diversity of their beliefs, culture or language; diversity within and between societies should not be filled with injustice and repression, but preserved as a valuable legacy of humanity; the culture of peace and dialogue between its civilisations should be actively promoted);

- respect for nature (prudence must be shown in the management of all living species and natural resources, in accordance with the precepts of sustainable development in order to ensure protection and preservation of the natural environment);

- sharing responsibilities (responsibility for managing the world economy and social development, as well as threats to international peace and security must be shared among nations of the world and should be carried out multilaterally). ${ }^{17}$

14 Proclamation on Ageing 1992, A/RES/47/5, 42nd plenary meeting, 16 October 1992 (Item 1 (j) and 3), http://www.un.org/documents/ga/res/47/a47r005.htm (accessed 5.12.2007).

15 See: L. Kozarčanin, The Process of Monitoring and Implementation of the Madrid Action Plan for Aging in Europe (Activities, Recommendations and Commitments), Socijalne teme (topic: Social Protection Development Strategy), Belgrade, Year XII, October-December, no. 4, 2005, p. 144-145.

16 Resolution 55/2, the United Nations Millennium Declaration, 8 September 2000 http://www.un.org/millennium/declaration/ares552e.htm (accessed 30.11.2007).

17 The implementation of the Millennium Declaration and its basic objectives was inter alia the subject of consideration in September 2005 at the level of the UN Economic Commission for Europe. See: Report to the Economic Commission for Europe, Sixtieth Annual Session, Geneva, 22-25 February 2005. This Report was drafted for the 60th Session of the UN Economic Commission for Europe (UNECE) held in Geneva 
The Second World Assembly on Aging was held in Madrid on 8-12 April 2002. Government representatives from around the world promoted the concept of "society for all generations" as an international response to the challenges of aging for the 21st century. As the UN Member States expressed concern about the speed and shape of the global aging process, the General Assembly adopted the Political Declaration and the Madrid International Action Plan on Aging, which obliges governments to face the aging challenges of the world. The Action Plan foresees 117 specific recommendations. ${ }^{18}$

The UN General Assembly noted the necessity of looking at the aging process in the context of the World Strategy against Poverty, as well as exerting efforts to achieve full participation in the world economy for all developing countries. This attitude was especially influenced by the scientific knowledge that the process of demographic aging will be the largest and fastest in the developing countries, considering that the elderly population there will increase by as much as four times by 2050 .

The Madrid Plan represents the first international agreement that specifically recognises the potential of older people to contribute to the development of their societies. The Plan obliges more than 160 governments to include aging in all aspects of social and economic development policies and to reduce poverty by 2015, in line with the Millennium Development Goals. The Plan aims to:

- ensure that aging should be incorporated into global development agendas;

- support the right of elderly people to participate equally in developmental sources;

- urge governments to include older people through national development and social policy processes (such as poverty reduction strategies and national development plans);

in February 2005. It refers to the monitoring of the Regional Strategy for the Implementation of the Madrid International Action Plan for Aging. The text of the Report was drafted in cooperation between the Government of the Republic of Austria, the UNECE Secretariat and the European Centre for Social Welfare and Research Policy. ITEM 8: Achieving the internationally agreed development goals, including those contained in the Millennium Declaration, as well as implementing the outcomes of major United Nations conferences and summits. Economic Commission for Europe, Annual report (27 February 2004-25 February 2005), Economic and Social Council, Official Records, 2005, Supplement No17, http://unece.org/commission/2005/ANNUAL_REPORT_2005.pdf (accessed 30.11.2007).

18 See: Political Declaration and Madrid International Action Plan on Ageing (MIPAA), https://www.un.org/esa/socdev/documents/ageing/MIPAA/political-declaration-en.pdf (accessed 11.11.2018); Main Content: Madrid International Action Plan on Ageing, http://www.helpage.org/Researchandpolicy/MadridInternationalPlanof ActiononAgeing / Background access: (accessed 30.11.2007); Report to the Second World Assembly on Ageing, http://www.un.org/esa/socdev/ageing/madrid_intlplanaction.html (accessed 30.11.2007). 
- contain detailed/elaborated sections on developmental areas relating to older people and their families, including: poverty, HIV, violence and abuse, access to health services and social protection;

- call for effective cooperation and partnership between governments, civil society, international agencies and the private sector with older people and their associations to achieve what is the subject matter of the Madrid Plan.

The key part of the accompanying Political Declaration"19 states: "We commit to eliminate all forms of discrimination, including age discrimination. We also recognise that people, as old people, should enjoy life in full measure, health, safety and be an active part of economic, social, cultural and political life in their societies. We are determined to increase the recognition of the dignity of the elderly and to eliminate forms of neglect, abuse and violence" (Article 5). Further on, Article 17 states: "Governments have a primary responsibility for providing leadership on aging issues and in the implementation of the International Action Plan on Aging (2002), but effective cooperation between national and local authorities, international agencies, elderly people and their organisations, and other parts of civil society, including non-governmental organisations and the private sector, is essential." Governments also underlined the "important role of the UN system, including the Regional Commissions, in assisting the Governments, at their request, in the implementation, monitoring and national monitoring of the International Action Plan on Aging, taking into account differences in the economic, social and demographic conditions between countries and regions" (Article 18).

The Action Plan includes 117 recommendations referring to three basic directions of priority actions identified:

a) Elderly people and their role in the development of society;

b) Improving health and well-being in the elderly;

c) Providing safe and supportive environment for elderly people's lives.

The Action Plan promotes new attitudes in relation to the emergence of aging. Aging cannot be considered unilaterally and only as a matter of social security and social protection (e.g., only as a question of one of the "life risks"), but as a process that takes place in every segment of society's life, in each development segment and in the overall developmental and the economic policy of one society. The Plan emphasises the need to promote a positive attitude to aging and to overcome the negative stereotypes on aging.

All the issues covered in the International Action Plan on Aging (2002) are aimed at improving the economic and social conditions in which elderly people live. Recommendations to Governments relate to areas such as:

19 See: Political Declaration (p. 9-12) and Madrid International Plan of Action on Ageing, https://www.un.org/esa/socdev/documents/ageing/MIPAA/political-declaration-en.pdf (accessed 11.11.2018). 
1. Ensuring the full exercise of all human rights and fundamental freedoms for all elderly people; ensuring the full exercise of economic, social and cultural rights as well as all civil and political rights, including participation in decision-making processes;

2. Improving the safety of older people includes the reaffirmation of the fight against poverty of older people and the development of society in line with the principles proclaimed by the UN for the elderly (adopted at the General Assembly in 1991);

3. Empowering elderly people to give full contribution and to participate effectively in the economic, political, cultural and social life of their societies, including income generation as well as volunteer work;

4. Providing opportunities for individual development in the elderly, personal achievements and access to old-age benefits, enabling access to education and life-long learning, and facilitating their full participation in any other segment of community life. ${ }^{20}$

The main challenge and difficulty is how to ensure that Governments of UN Member States will meet the commitments. In that regard, paragraph 114 reads: "The implementation of the International Action Plan 2002 will ensure sustainable actions at its levels (...) It will provide a systematic evaluation in response to new challenges (...)." ${ }^{21}$ Paragraph 118 reads that "efforts should be made to promote the institutional monitoring of the International Action Plan 2002, including as an appropriate establishment of agencies for the issue of aging and national committees (...)." UN Regional Commissions are responsible for developing implementation strategies in their regions, and the UN Commission for Social Development oversees how governments implement the Plan. A systematic overview of the implementation of the International Action Plan 2002 by UN Member States is essential for its success in improving the quality of life of the elderly. The mutual exchange of outcomes in a regular overview of implementation between countries will, in the following period, have a special value (paragraph 131).

The plan does not oblige governments or the international community to provide additional resources for implementing the content of the document. This means that the resources available are, in fact, available from poverty reduction programmes within individual countries. In the whole process of implementation of the Action Plan, the elderly and their associations play a vital role. By monitoring the process, they should ensure that the governments of the signatory states act in accordance with

20 Madrid International Action Plan on Ageing (MIPAA) (Advance unedited copy), ISSUE 1: Active participation in society and development (21. Objective 1: Recognition of the social, cultural, economic and political contribution of older persons; Actions) https://www.un.org/esa/socdev/documents/ageing/MIPAA/political-declaration-en. pdf (accessed 10.10.2017).

21 See: Madrid International Plan of Action on Ageing (MIPAA). 
the recommendations envisaged in the Plan. As active participants in the process, they should be concerned that aging, as a phenomenon, should be integrated into national poverty reduction programs and related initiatives in order to achieve the Millennium Development Goals. ${ }^{22}$

The Governments of the UN Member States have committed, through their representatives in these documents, to undertake specific national activities but also to participate in mutual cooperation, not only for the purpose of implementing the agreed policy in the field of aging but equally ensuring the systematic and active monitoring of the policy's implementation.

\section{Council of Europe and the European Union}

On 19 December 1953, the Council of Europe adopted the European Interim Agreement on Social Security Schemes Relating to Old Age, Invalidity and Survivors and Protocol Thereto, envisaging a social security plan of contributory and non-contributory benefits for the elderly, disabled and survivors. In Article 1 of the European Interim Agreement, it is stipulated that the provisions of the document will be incorporated in all legal texts and other legal regulations relating to social security in the countries that are signatories to the Agreement. These provisions concern the welfare of the elderly, people with disabilities (invalidity) and survivors (from the Second World War, cf.). ${ }^{23}$

The 1997 Amsterdam Treaty contained the first provisions adopted at EU level to establish a process of enacting anti-discrimination laws based on age. The agreement was made possible by the European Council, a judicial body with the task of determining a general strategy among the Member States in order to take action to combat discrimination on grounds of age. This treaty was the cornerstone for drafting the Framework Employment Equality Directive, endorsed by a large number of EU Member States and finally adopted in 2000 (Charters, 2008: 40). ${ }^{24}$

The Framework Employment Equality Directive $(2000)^{25}$ was the first legal regulation adopted at EU level designed to prescribe the principles

22 See: Madrid International Plan of Action on Ageing (MIPAA).

23 See: European Interem Agreement on Social Security Schemes Relating to Old Age, Invalidity and Survivors and Protocol Thereto (1953), Council of Europe, European Treaty Series - No. 12 - Social Security (Interim Agreement), Paris, 19 December 1953; http://www.worldlii.org/int/other/COETS/1953/1.html (accessed 11.11.2018).

24 Stephen Ch., Age Related Policies: A Global Review on Age Discrimination Legislation, January 2008., International Federation on Ageing, p. 40-46; https://www.antidiskriminierungsstelle.de/SharedDocs/Downloads/DE/Literatur_Altersjahr/Age_related_policies.pdf?_blob=publicationFile\&v=1 (accessed 11.11.2018).

25 Framework Employment Equality Directive (2000), Council Directive 2000/ 78/EC of 27 November 2000 establishing a general framework for equal treat- 
of equality among all citizens (irrespective of age, disability or sexual orientation) in employment and at workplace, as well as when assisting them in the choice of occupation and membership in institutions dealing with employment. Long before the adoption of the Directive, the European institutions had issued a large number of legal acts including nondiscrimination on other grounds, such as gender, yet it was only in the mid1990s that those acts begin to apply to other forms of unequal treatment based on age or disability.

The Directive sets minimum standards for recognising age discrimination in employment (Recital 25), which Member States are required to incorporate into their domestic legislation (Article 4 (2)). All forms of direct and indirect discrimination and sexual harassment are forbidden (Recital 12). Direct discrimination refers to an act that puts a group or an individual in a less favourable position in relation to another group or individual. Indirect discrimination refers to a situation where a seemingly neutral provision, criterion or practice puts a group or an individual of a particular age, disability of sexual orientation at a disadvantage as compared with other persons. (Article 2(1) and Article 2(2)). The Directive also includes a provision that invalidates any laws, regulations and administrative acts that are contrary to the principle of equal treatment (Article 16 of the Employment Equality Directive).

On the other hand, the Directive envisages exceptions for different treatment in justified cases (positive discrimination). Thus, the provisions allow for different treatment on the basis of age in limited circumstances, "where a characteristic related to religion or belief, age or sexual orientation constitutes a genuine and determining occupational requirement, when the objective is legitimate and the requirement is proportionate" (Recital 23) as well as "positive action to promote the employment and training of disabled people" (Recital 27). Yet, the different treatment must be justified by a legitimate aim (employment policy, labour market and vocational training, equal employment opportunities, life-long learning, etc.) (Recitals 25 and 27). Under this Directive, persons who have been subject to discrimination on the grounds of age, disability or sexual orientation should enjoy adequate legal and judicial protection (Recitals 29 and 30).

The EU Member States were required to adopt legislation in compliance with the Directive and implement the legal provisions on employment equality related to age until December 2003 (Article 18 of the Directive). They were also granted a three-year period (until 2006), when they had to report to the European Commission on the application of this Directive, for each year individually (Article 18 of the Directive).

ment in employment and occupation, https://eur-lex.europa.eu/legal-content/EN/ TXT/?uri=celex\%3A32000L0078 (accessed 11.11.2018). 
In line with the 2000 Framework Employment Equality Directive, the United Kingdom adopted the Employment Equality Regulations (EER, 2006), ${ }^{26}$ which included all the definitions of discrimination provided for in the Directive and explicitly referred to the prohibition of all forms of age discrimination, unfavourable treatment, hostility and harassment based on age, instructing another to commit an act of discrimination, or victimisation of an individual that has made a discrimination claim (Part 1, Articles 3-6 EER). The Employment Equality Regulations allow differential treatment in cases where it is justified by the "nature of the employment or the context in which it is carried out", where "possessing a characteristic related to age is a genuine and determining occupational requirement", and where "it is proportionate to apply the requirement in the particular case" for the purpose of a legitimate aim (Part 2, Article 8(2) of the EER). Establishing an employment practice of differential treatment on the basis of age (positive action) must demonstrate that the "benefits of such a practice significantly outweigh the importance of prohibiting discrimination, and must be the only reasonable choice available to the employer" (Charters, 2008: 42). Some exception where age differentiation may be justifiable include cases of statutory authority, national security, positive action, retirement, national minimum wage, life insurance, and benefits based on length of service (Part 4, Articles 27-34 of the EER). Mandatory retirement is permissible when legitimate employment requirements are linked to age. Thus, employers are not obliged to employ a person who is 65 or over the age of 65 (Charters, 2008: 42).

Any discriminatory act which is contrary to the Directive provisions is actionable and the injured party may file a complaint with an employment tribunal (Part 5, Article 36 of the EER), which is established within the institutional framework of the Department of Labour and Pensions. Exceptions to this procedure include cases of discrimination within higher education institutions and breach of a statutory duty of employers and principals, when the claimant must file a civil claim to initiate civil proceedings (Part 5, Article 39 of the EER). In case of age-based discrimination, the injured party is entitled to seek relevant legal remedies: monetary compensation, court order, and guidelines for the respondent to avoid future discrimination (Charters, 2008: 43).

In spite of the obligation of the Member States to enact legislation in compliance with the Directive, concerns were expressed in the UK about the implementation of the Directive and expected long-term results. In the UK, which was among the last EU states that adopted legislation in accordance with the Directive, it was pointed out that age-based discrimination is the most common form of discrimination in the workplace (BBC News, 2005).

26 Employment Equality (Age) Regulations, 2006, No. 1031, http://www.legislation. gov.uk/uksi/2006/1031/contents/made (accessed 11.11.2018). 
The director of the Employers Forum on Age said: "As our research has confirmed, ageism is endemic in our society and rife in our workplaces. These attitudes need to be challenged so that they become as unacceptable as sexism or racism. (...) We all have a lot of work to do to ensure ageism becomes a thing of the past. Now that the legislation is here, both employers and individuals need to catch up fast on what it means for them and their workplace."27 (Charters, 2008: 45) The result of research by the Ludic Group revealed that "age discrimination is believed to be more acceptable than other forms of discrimination. The research suggests that legislation alone will not resolve the problems in Britain's workplaces because people do not take age discrimination as seriously as they do prejudices based on race or religion." ${ }^{28}$ Thus, deep cultural changes in attitude are needed to complement the existing legislation and make it really applicable (Charters, 2008: 45).

As a separate piece of legislation, the Employment Equality Regulations (2006) was a short-lived document because in 2007 the UK government entered consultations on introducing a Single Equality Bill designed to unify the nine existing discrimination Acts into a single act (Charters, 2008: 43) in order to simplify the system and provide for more effective protection against all forms of discrimination. The new Equality Act 2010 came into force on 1 October 2010, providing a legal framework for equal treatment (equal employment opportunities, equal pay) and legal protection against different forms of discrimination based on sex/gender, age, disability, race, religion or belief, sexual orientation, etc. ${ }^{29}$

In June 2004, the European Union adopted the Treaty establishing a Constitution for Europe (TCE), ${ }^{30}$ which was aimed at unifying the existing $\mathrm{EU}$ treaties into a single consolidated constitution of the EU. This document was largely criticised by the professional public because it was perceived as a "step backwards to the 1948 Universal Declaration of Human Rights", by

27 S. Mercer: Management Issues 2006, cited in: Charters, 2008: 45.

28 Amble "Legislation 'Not the Answer to Ageism"' 2005, cited in: Charters, 2008: 45.

29 See: Introduction to the Equality Act 2010, Equality and Human Rights Commission, United Kingdom; https://www.equalityhumanrights.com/en/equality-act-2010/ what-equality-act (accessed 11.11. 2018). For more, see: Equality Act 2010: Guidance, Government Equality Office and Equality and Human Rights Commission, published on 27 February 2013, https://www.gov.uk/guidance/equality-act-2010-guidance (accessed 11.11. 2018).

30 The Treaty establishing a Constitution for Europe (TCE), commonly referred to as The Constitutional Treaty or The European Constitution (2004). The proposal of the Constitutional Treaty was adopted by the Heads of EU States and Governments in June 2004, signed by 25 EU Members States and ratified by 17 EU Member States by the end of 2005. See: R. Streinz, "The European Constitution after the Failure of the Constitutional Treaty", Zeitschrift für öffentliches Recht (ZÖR 63 (2008), Summary, Springer-Verlag 2008, https://link.springer.com/article/10.1007/s00708-008-0208-7 (accessed 11.11.2018). 
stating that every person has the right to living conditions sufficient to take care of one's own health, the right to acceptable quality of life for themselves and their families (...), the right to security in case of unemployment, sickness, disability, widowhood, age and in all other cases of loss of ability to provide for one's livelihood. The Constitution for Europe does not regulate issues such as minimum wages, pensions and family allowances, which would be a prerequisite for decent living conditions and create a sense of community for all Europeans. Women are considered to be in a particularly difficult situation. "Older women face higher problems than older men, as more than $20 \%$ of older women are at risk of poverty or social exclusion, cutting on basic needs such as health care. The gender pension gap remains high at 37 percent." ${ }^{31}$ In the context of women's underprivileged position, Article II-94 of the TCE titled "Social Security and Social Assistance" prescribes that the EU "recognises and respects the entitlement to social security benefits and social services providing protection in cases such as maternity, illness, industrial accidents, dependency or old age, and in the case of loss of employment" in accordance with EU laws, national laws and practices (Article II-94 of the TCE). Thus, inter alia, it provides grounds for the legal protection of the elderly.

\section{Problems and Solutions}

Abuse of elderly persons is typically unrecognised, underreported and inadequately addressed. In 2011, the UN General Assembly adopted its Resolution 66/127, where 15 June was designated as World Elder Abuse Awareness Day ${ }^{32}$. It is a way to engage international and regional as well as national and local organisations, civil society and individuals in activities aimed at raising awareness about elderly abuse, neglect and exploitation as a global issue. Typically, these activities include: educational programmes and press conferences; providing volunteers willing to visit isolated elderly persons who may be in danger of becoming a victim of abuse, neglect or exploitation; carrying out other activities aimed at developing awareness about elderly abuse, such as writing and publishing articles in local newspapers, etc. One way of preventing the victimisation of the elderly is the establishment of long-term protection programmes, such as the US Long-Term Care Ombudsman Programme. ${ }^{33}$ In the USA, this

31 See: https://www.age-platform.eu/policy-work/news/pension-adequacy-2018\% C2\%A0many-challenges-still-come (accessed 16.11.2018).

32 UN Department of Economic and Social Affairs: Aging, World Elder Abuse Awareness Day, https://www.un.org/development/desa/ageing/world-elder-abuse-awarenessday.html (accessed 11.11. 2018).

33 See: Long-Term Care Ombudsman Program, Administration for Community Living, https://acl.gov/programs/protecting-rights-and-preventing-abuse/long-termcare-ombudsman-program (accessed 11.11. 2018). 
initiative started in 1972 and thousands of Ombudsman-designated staff and volunteers have participated in it ever since. The representatives of this programme provide assistance to residents of nursing homes, assisted living and other residential care communities, helping the elderly resolve everyday problems related to health, safety, welfare and individual rights.

In the United States, the US Department of Health and Human Services established a specific agency called the Administration on Aging (AoA), ${ }^{34}$ which is responsible for providing services and support to the elderly in compliance with the 1965 Older Americans Act, subsequently amended (US Code Title 42 Public Health and Welfare $\$ 3001$ et seq.). ${ }^{35}$ In developed countries, efforts of all similar government agencies are always aimed at keeping the elderly in their homes and ensuring their active participation in the life of the local community, which is often hindered by their financial exploitation and fraud. Thus, the scope of work of the US Administration on Aging (AoA) agency includes raising awareness of users of their services, preventing victimisation of elderly persons, promoting their active participation in the local community, as well as preventing fraud, mistreatment and abuse of elderly people in related services such as the Medicaid (Health Protection of the Poor) and Medicare (Health Protection of Old People within Social Security). By informing and training older volunteers, the staff working on connecting old people, as well as those providing care for the elderly, the AoA aims to enable the aging Americans and their representatives to use health care and other supportive services in a much better way. The state can encourage elderly people to plan their lives ahead, make provisions for the prospective incapacitation and organise their lives so as to postpone or prevent this incompetence, but these efforts cannot be achieved by the elderly who lose their savings or their homes as a result of being victims of fraud or falling into the trap of financial exploitation. Thus, fraud and financial exploitation are considered to be the main threats to the wellbeing of elderly people. According to a survey by the National Elder Abuse Incidence Study, the number of financial fraud cases involving the elderly increases every year with relation to the number of physical abuse cases.

Financial institutions are often first to recognise abuse, fraud and exploitation of an elderly person or a vulnerable adult, usually performed

34 See: Administration on Aging (AoA), Administration for Community Living (ACL), https://acl.gov/about-acl/administration-aging. In comparison, the Serbian Ministry of Labour and Social Policy manages the family and social care sectors but age and aging issues are not explicitly mentioned as specific fields of its work. See: https:// www.minrzs.gov.rs (accessed 28.10.2017).

35 See: Older Americans Act (OAA), Administration for Community Living (ACL), https://acl.gov/about-acl/authorizing-statutes/older-americans-act; \& Title 42 Public Health and Welfare $\$ 3001$, https://codes.findlaw.com/us/title-42-the-public-healthand-welfare/42-usc-sect-3001.html (accessed 11.11.2018). 
by relatives or a person entrusted to take care of an elderly person. Thus, a temporary or permanent contact between the financial institution and the elderly person as a client is a unique opportunity for the institution to report a suspected fraudulent activity to the AoA agency for further investigation. In order to prevent the financial exploitation of elderly people, some state agencies organise trainings for bank employees. ${ }^{36}$

Developed countries have special laws that provide for the protection of the guaranteed rights of elderly people. Thus, the US Older American Act of 1965 envisages that old people should be provided with 1) an adequate income in retirement, in accordance with the American living standard; 2) the best possible medical care in the field of physical and mental health that can be made available by science, irrespective of the economic status of the user; 3) suitable housing, independently selected, designed and located with reference to special needs and available at affordable prices; 4) restorative services that would provide full institutional care for the elderly and long-term community-based services as support to family members and caregivers; 5) opportunity for employment without agebased discriminatory practices; 6) retirement in the circumstances of health, honour and dignity, after years of employment and contribution to the economy; 7) active participation in meaningful activities and contribution to the local community within a wide range of civic, cultural and recreational opportunities; 8) efficient utility services, including access to low-cost transportation, which provide a choice in supported living arrangements and coordinated social assistance, easily accessible to vulnerable individuals when needed; 9) immediate benefit from the proven research findings that can sustain and improve elders' health and happiness; 10) freedom, independence and free exercise of individual initiatives in planning and managing their own lives, and full participation in planning and operation of community-based services and programs provided for their benefit and protection against abuse, neglect and exploitation (Title I Sec. 101 (1-10), Older Americans Act of 1965). ${ }^{37}$

36 Using the support of the AoA agency, this type of partnership was developed between the APS service and Wachovia Bank. The APS trained bank staff and improved access to files in order to prevent the financial exploitation of the elderly. This partnership has shown remarkable results and was later used as a good practice model, known as BITS Financial Services Roundtable, at the Committee of the National Consortium of Banks for Reducing Fraud. The bankers' response was enthusiastic and contributed to the extensive use of this model at the national level within the banking system. See: Department of Health and Human Services, Administration of Aging, Elder Rights, http://www.aoa.gov/eldfam/Elder_Rights/Preventing_Fraud/Preventing_Fraud.asp (accessed 17.10.2007).

37 Title I Sec. 101 (1-9), Older Americans Act of 1965, as amended through P.L. 114-144, 19 April 19 2016, https://legcounsel.house.gov/Comps/Older\%20Americans\%20Act\%20Of\%201965.pdf. 
As a final consideration in this theoretical research on the prevention of discrimination and victimisation of elderly people, we may conclude that society cannot be reduced to social relations among people living at present; it also includes our relations with the past and future. We are all indebted to the past generations, and this debt gives rise to our obligations to the future generations. If we value our own life, then we should appreciate and respect those who made this life possible, our own families and past societies that ensured human existence.

Therefore, in order to ensure a dignified life and wellbeing of elderly people, we should look up to the legal solutions enacted at international and regional levels (UN, EU, CE) as well as good practices in some developed counties. In order to prevent the victimisation of the elderly and provide for their full legal protection, the analysed documents and good practices should serve as guidelines in resolving the daily problems encountered by the elderly in the fields of medical care, safety, housing, financial resources, social welfare, individual rights and general wellbeing. To this effect, these good practices should be incorporated into national legislation or implemented in addressing social policy issues within the national legislative framework.

\section{Bibliography}

Administration on Aging (AoA), Administration for Community Living (ACL), available at: http://www.aoa.gov/eldfam/Elder_Rights/Preventing_Fraud/Preventing_Fraud.asp (accessed 17.10.2007), https://acl.gov/about-acl/administration-aging (accessed 17.10.2017).

Charters S., Age Related Policies: A Global Review on Age Discrimination Legislation, January 2008, International Federation on Ageing, p. 40-46, https://www.antidiskriminierungsstelle.de/SharedDocs/Downloads/DE/Literatur_Altersjahr/ Age_related_policies.pdf?_blob=publicationFile\&v $=1$ (accessed 11.11.2018).

Declaration on Social Progress and Development 2542 (XXIV) 11.12.1969, https:// www.ohchr.org/Documents/ProfessionalInterest/progress.pdf (accessed 16.11. 2018).

Department of Health and Human Services, Administration of Aging, Elder Rights, http://www.aoa.gov/eldfam/Elder_Rights/Preventing_Fraud/Preventing_ Fraud.asp (accessed 17.10.2007).

Employment Equality (Age) Regulations, 2006, No. 1031, http://www.legislation. gov.uk/uksi/2006/1031/contents/made (accessed 11.11.2018).

European Interim Agreement on Social Security Schemes Relating to Old Age, Invalidity and Survivors and Protocol Thereto (1953), Council of Europe, European Treaty Series - No.12 - Social Security (Interim Agreement), Paris, 19.12.1953, http://www.worldlii.org/int/other/COETS/1953/1.html (accessed 11.11.2018).

Equality Act 2010 (UK): Guidance, Government Equality Office \& Equality and Human Rights Commission, published on 27 February 2013, https://www.equalityhumanrights.com/en/equality-act-2010/what-equality-act \& https://www. gov.uk/guidance/equality-act-2010-guidance (accessed 11.11. 2018). 
Framework Employment Equality Directive (2000), Council Directive 2000/78/EC of 27 November 2000 establishing a general framework for equal treatment in employment and occupation, https://eur-lex.europa.eu/legal-content/EN/ TXT/?uri=celex\%3A32000L0078 (accessed 11.11.2018).

Konstantinović-Vilić S., Kostić M., Miladinović D., Pravo na pravnu pomoć i kvalitet pravne pomoći pružene građanima u krivičnom postupku i postupku izdržavanja kazne [The right to legal aid and quality legal assistance rendered to citizens in criminal proceedings and the procedure for serving sentences], Centar za publikacije, Pravni fakultet, Univerzitet u Nisu, 2007.

Kozarčanin L., "Proces praćenja i implementacije Madridskog plana akcije za starenje u Evropi (Aktivnosti, preporuke i obaveze)", [The Process of Monitoring and Implementation of the Madrid Action Plan for Aging in Europe: Activities, Recommendations and Commitments], Socijalna misao (topic: "Strategija razvoja socijalne zaštite”) [Social Protection Development Strategy), Belgrade, Year XII, October December, no. 4, 2005, p. 144-145.

Long-Term Care Ombudsman Programme, Administration for Community Living, https://acl.gov/programs/protecting-rights-and-preventing-abuse/long-termcare-ombudsman-program (accessed 11.11.2018).

Madrid International Action Plan on Ageing; http://www.helpage.org/Researchandpolicy/ MadridInternationalPlanofActiononAgeing / Background (accessed 30.11.2007) Report to the Second World Assembly on Ageing, http://www. un.org/esa/socdev/ageing/madrid_intlplanaction.html (accessed 30.11.2007).

Ministarstvo rada i socijalne politike Republike Srbije (Serbian Ministry of Labour and Social Policy), https://www.minrzs.gov.rs (accessed 28.10.2017).

Political Declaration and Madrid International Action Plan on Ageing (MIPAA) (Advance unedited copy), https://www.un.org/esa/socdev/documents/ageing/ MIPAA/political-declaration-en.pdf (accessed 10.10.2017).

Older Americans Act of 1965, as amended by P.L. 114-144, 19 April 2016, https:// legcounsel.house.gov/Comps/Older\%20Americans\%20Act\%20Of\%201965. pdf (accessed 10.10.2017).

Older Americans Act (OAA), Administration for Community Living (ACL), https://acl.gov/about-acl/authorizing-statutes/older-americans-act; \& Title 42 Public Health and Welfare $\$ 3001$, https://codes.findlaw.com/us/title-42-the-public-health-and-welfare/42-usc-sect-3001.html (accessed 30.11.2007).

Proclamation on Ageing 1992, A/RES/47/5, 42nd plenary meeting, 16 October 1992 (Item 1 (j) and 3), http://www.un.org/documents/ga/res/47/a47r005.htm (accessed 5.12.2007).

Resolution 32/131 Question of the elderly and the aged, 16 December 1977, http:// www.un.org/documents/ga/res/32/ares32r131.pdf (accessed 3.12.2007).

Resolution 32/132 International year and world assembly on aging, 16 December 1977, http://www.un.org/documents/ga/res/32/ares32r132.pdf (accessed 3.12.2007).

Resolution 33/52 World Assembly on the Elderly, 14 December 1978, http://www. un.org/documents/ga/res/33/ares33r52.pdf (accessed 3.12.2007).

Resolution 37/51 Question of Ageing, 3 December 1982, http://www.un.org/documents/ga/res/37/a37r051.htm (accessed 10.9.2018).

Resolution 55/2, The United Nations Millennium Declaration, 8 September 2000, http://www.un.org/millennium/declaration/ares552e.htm (accessed 30.11.2007). 
Resolution 2599 (XXIV) Question of the elderly and the aged, 16 December 1969, https://documents-dds-ny.un.org/doc/RESOLUTION/GEN/NR0/257/33/ IMG/NR025733.pdf?OpenElement (accessed 14.11.2018).

Resolution 2842 (XXVI) Question of the elderly and the aged, 18 December 1971, accessed 14.11.2018 https://documents-dds-ny.un.org/doc/RESOLUTION/ GEN/NR0/328/58/IMG/NR032858.pdf?OpenElement.

Resolution 3137 (XXVIII) Question of the elderly and the aged, 14 December 1973, https://documents-dds-ny.un.org/doc/RESOLUTION/GEN/NR0/282/09/ IMG/NR028209.pdf?OpenElement (accessed 15.11.2018).

Report to the Economic Commission for Europe, Sixtieth Annual Session, Geneva, 22 -25 February 2005. Millennium Declaration, as well as implementing the outcomes of major United Nations conferences and summits. Economic Commission for Europe, Annual Report (27 February 2004-25 February 2005), Economic and Social Council, Official Records, 2005, Supplement No17, http://unece.org/commission/2005/ANNUAL_REPORT_2005.pdf (accessed 30.11.2007).

Streinz R., "The European Constitution after the Failure of the Constitutional Treaty”, Zeitschrift für öffentliches Recht (ZÖR 63 (2008), Summary, Springer-Verlag 2008, https://link.springer.com/article/10.1007/s00708-008-0208-7 (accessed 11.11.2018).

UN Department of Economic and Social Affairs: Aging, World Elder Abuse Awareness Day, https://www.un.org/development/desa/ageing/world-elder-abuse-awareness-day.html.

UN - Key conference outcomes on ageing, http://www.un.org/esa/devagenda/aging. html (accessed 30.11.2007).

United Nations Principles for Older Persons, https://www.ohchr.org/Documents/ ProfessionalInterest/progress.pdf (accessed 11.11.2018).

AGE Platform Europe, Pension Adequacy 2018, https://www.age-platform.eu/policy-work/news/pension-adequacy-2018\%C2\%A0many-challenges-still-come (accessed 16.11.2018).

Abstract

In every developed social system, the prevention of discrimination and victimisation of elderly persons is one of the most important indicators of the overall status and social position of this vulnerable social group. In the specific circumstances of the social environment, the social position of elderly persons is largely determined by their specific living circumstances, their status of unemployed (retired) persons, as well as by the fact that they may be perceived as an economical, emotional and social burden to the younger generations. Yet, it is a matter of fact that all active (currently employed) persons will eventually become part of the inactive (retired) population. Elderly persons have already given their contribution to society and social progress, which entitles them to expect assistance and protection from society during the "third" and "fourth" periods of their lives. If young persons have the power to make decisions and lead society, they also have the power to exert significant impact on the social position and quality of life of the elderly, and thus contribute to improving the quality of their own future. The issue of victimisation of the elderly is usually associated with a high "dark number" The great risk of the victimisation of elderly persons depends on their per- 
sonal predispositions linked to the end of the physical processes in the human body as well as the psychological changes affecting the elderly during the "third" age. In this article, the authors examine the tendencies in the regulations of this subject matter in legal documents issued by some international and regional organisations (the UN, the EU and the CoE), which serve as examples of good practices in addressing social policy issues related to the elderly.

Keywords: the elderly, international documents, social policy, UN, Council of Europe, EU

\section{Dziedzictwo ONZ i państw europejskich w zakresie polityki społecznej wobec osób starszych}

Streszczenie

W każdym rozwiniętym systemie społecznym jednym z najważniejszym wskaźników ogólnego statusu i pozycji społecznej osób starszych jest zapobieganie dyskryminacji i krzywdzeniu tej defaworyzowanej grupy. W konkretnych okolicznościach środowiska społecznego pozycja osób starszych jest w dużej mierze determinowana ich warunkami bytowymi, statusem niepracującego (emeryta) oraz faktem, że mogą być one postrzegane jako ekonomiczny, emocjonalny i społeczny ciężar dla młodszych pokoleń. Faktem jest jednak, że wszystkie aktywne (obecnie zatrudnione) osoby w końcu staną się kiedyś członkami populacji nieaktywnej (zostaną emerytami). Osoby starsze wniosły już swój wkład w społeczeństwo i postęp społeczny, co sprawia, że mają prawo oczekiwać wsparcia i ochrony ze strony społeczeństwa w „trzecim” i „czwartym” okresie życia. Jeśli młodzi mają moc podejmowania decyzji i przewodzenia społeczeństwu, mogą również wywrzeć znaczący wpływ na pozycję społeczną oraz jakość życia osób starszych, a tym samym na polepszenie jakości swej własnej przyszłości. Zazwyczaj podaje się, że liczba osób starszych będących ofiarami nadużyć jest bardzo wysoka i trudna do określenia. Ryzyko wiktymizacji zależy od osobistych predyspozycji powiązanych z końcem procesów fizycznych w ludzkim ciele oraz psychologicznymi zmianami dotykającymi osoby starsze w „trzecim wieku”. Autorzy niniejszego artykułu badają trendy regulacyjne dotyczące omawianego obszaru w dokumentach prawnych niektórych organizacji o charakterze międzynarodowym i regionalnym (ONZ, UE, KE), które służą jako dobre przykłady zajmowania się problemami socjalnymi dotyczącymi osób starszych.

Słowa kluczowe: osoby starsze, dokumenty międzynarodowe, polityka społeczna, ONZ, Rada Europy, UE 